\title{
Growth and yield performance of rice cultivars (Oryza sativa L.) under seaweed extract and inorganic fertilizer
}

\author{
Helen Grace Guillermo Sebastian \\ Agriculture Department, Isabela State University, Jones, Isabela 3313, Philippines \\ *Email: lhenguisebastian06@yahoo.com
}

ARTICLE HISTORY

Received: 25 December 2020

Accepted: 12 June 2021

Available online: 10 October 2021

\section{KEYWORDS}

Grain

Panicle

Seaweed Extract

Tillers

Upland Rice

Yield
ABSTRACT

A field experiment was conducted once at Isabela State University, Jones, Isabela, Philippines during the wet season of 2018 to determine the impact of seaweed extract added with varying levels of inorganic fertilizer on the growth and yield of upland rice (Oryza sativa L.) cultivars. In the study, five fertilizer levels and a farmer's practice as a control combined with seaweed extract was used. The study used Randomized Blocks in a Factorial Scheme with six treatments replicated thrice as follows: Factor A: $\mathrm{V}_{1}$-Pinilisa, $\mathrm{V}_{2}$-Palawan and Factor B: F1-150-100 kg NP ha ${ }^{-1}$ (Farmer's Practice), F2-40-10 kg NP ha ${ }^{-1}$ (100\% Recommended Rate), F3-20-5 kg NP ha-1 (50\% Recommended Rate), F4-40-10 kg NP ha-1 $+3 \mathrm{~L} / \mathrm{ha}$. Seaweed extract, F5-20-5 kg NP ha ${ }^{-1}+3 \mathrm{~L} / \mathrm{ha}$. Seaweed extract and F6-3L/ha. Seaweed Extract. The findings revealed that seaweed extract combined with inorganic fertilizer application influenced the growth and yield of rice. Pinilisa cultivar obtained a higher yield compared to the Palawan cultivar. The combination of seaweed extract and inorganic fertilizer shows highly significant differences especially concerning the number of productive tillers, filled grains, 1000 grain weight and straw weight. The return on investment showed that Pinilisa cultivar fertilized with $3 \mathrm{~L}$ seaweed extract is more economical in upland rice obtaining the highest with $95.47 \%$. Seaweed extract as foliar fertilizer can be applied not only in rice but also in other crops. Application of seaweed extract on rice can reduce the amount of fertilizers.

\section{Introduction}

Jones, Isabela is well-known for Pinilisa and it is registered as the One Town One Product (OTOP) of the municipality. It is a variety of upland rice (O. sativa L.) grown in the municipality, renowned for its distinctive color and fragrance. Palawan, noted for its poor productivity, is a typical upland rice cultivar that cannot be grown during the year. One valuable strategy to increase its productivity is through seaweed extract application. Application of seaweed extract on rice can reduce the amounts of nitrogen, phosphorus and potassium fertilizers. Traditional upland rice (O. sativa) cultivars are one of the main staple crops in the upland production system in the Philippines and Asia (1, 2). However, traditional upland rice is mostly grown in marginal upland areas with highly degraded, infertile and acidic soils. Traditional upland rice is usually aromatic, tall and late maturing and is usually grown organically, with lesser cultural practices or management intervention. These practices resulted in its lower yield, thus, treated only as a subsistence crop (3).
Nitrogen $(\mathrm{N})$ and phosphorus (P) are essential elements for proper growth and development of crops which significantly increases and enhances the yield to feed the increasing global population (4). Nitrogen and phosphorus are essential to the development of crop because they form the basic component of many organic molecules, nucleic acids and proteins (5).

Rice production in the province of Isabela, Philippines is lower in 2019 compared to the previous year which was due to the decrease in the areas harvested or unplanted rainfed areas (6). Rice plays a significant and leading role in crop production in more or less 100000 ha upland areas in the Philippines. It is a key crop in agricultural land use. Thus, increasing its yields is a determining factor to secure food and reduce poverty in the country (7) by seaweed extract application which is a low-cost and potential plant bio-stimulant applied as foliar spray (8).

Efficient improvement of the nutrient is chiefly important in increasing both the use of fertilizer and the yield of rice (9). The adoption of developed

(c) Sebastian (2021). This is an open-access article distributed under the terms of the Creative Commons Attribution License, which permits unrestricted use, distribution and reproduction in any medium, provided the original author and source are credited (https://creativecommons.org/licenses/by/4.0/). 
technologies to increase rice yield can attract farmers to shift from corn and cassava cultivation into upland rice production. Proper management practices of nutrients is an essential component of rice production technology to ensure higher rice productivity.

Upland rice cultivation was more favorable to save water and reduce irrigation and evaporation (10). Besides, it is also known to reduce greenhouse gas emissions, as well as methane, vapor and carbon dioxide, because of the environmentallyfriendly irrigation practice as compared to traditional rice farming.

Synthetic fertilizer application plays a vital role in improving rice grain yield, which has been considered as an effective channel to address the food security issue due to an increasing population. Proper application of organic and inorganic fertilizer is important in using nutrients efficiently in rice need-based rate of fertilizer application, appropriate methods and timely application of fertilizers. Efficient nutrient management in rice has paramount significance for improving yield and profitability in short term and better ecological management services in the long-term perspective. The complete fertilizers are an important and easily available fertilizer source of nutrients that can meet the nutrient requirement of plants but their low availability to crop due to leaching and other losses lead to low yield $(11,12)$.

Seaweed liquid extract has newly gained importance as a foliar spray for many crops as well as a variety of grasses, flowers, cereals, vegetables and spices (13). The application of liquid seaweed fertilizers on various crop species can lower the application dosage of nitrogen, phosphorus and potassium and also stimulating plant growth and yield (14). Seaweed extract is effective in increasing the growth parameters (plant height, number of plants per square meter, number of pods per plant, number grains per pod, number of branches per plant and test weight), yield and enhancing nutrient uptake by the plants (15). This can reduce excessive fertilizer application for yield enhancement and showing an effective response against various pests and diseases (16).

Seaweed extracts as natural plant growth stimulants could be significantly used as a good agricultural practice in sustainable and organic crop production (17). Seaweed extracts are rich in micro and macronutrients, polysaccharides, proteins, polyunsaturated fatty acids, polyphenols, phytohormones and osmolytes that can stimulate the growth and yield of crops, elicit multiple beneficial effects in crops, including enhanced germination and establishment of seed, overall plant growth and productivity $(18,19)$, resistant against stresses (biotic and abiotic) (20). Moreover, seaweed extracts were biologically degradable, nonpolluting and non-toxic for the environment and the use of the seaweed extract increased significantly $\mathrm{N}$, $\mathrm{P}$ and $\mathrm{K}$ uptake by grains (15). Seaweed extract enhanced crop yield, improved root structures, improved plant development like flowering and leaf development and fruit set and enhanced ability to tolerate plant disease and climatic stresses such as cold or drought (21). Likewise, improved soil structure, soil water holding capacity and improved soil microbiology. Due to the positive result of seaweed to some crops (22), the foliar application of seaweed extract will allow lessening fertilizer costs and safe for the environment.

This study was conducted to determine the impact of seaweed extract in combination with different levels of inorganic fertilizer on the growth and yield of two upland rice cultivars for one cropping season of 2018 at the experimental area of Isabela State University, Jones, Isabela, Philippines. It specifically aimed to determine which levels of seaweed extract and inorganic fertilizer increase the growth and yield of two upland rice cultivars and identify which among the different treatments would give the best result in terms of return on investment. Fig. 1 shows the photos and variations of the two upland rice cultivars used in the study.

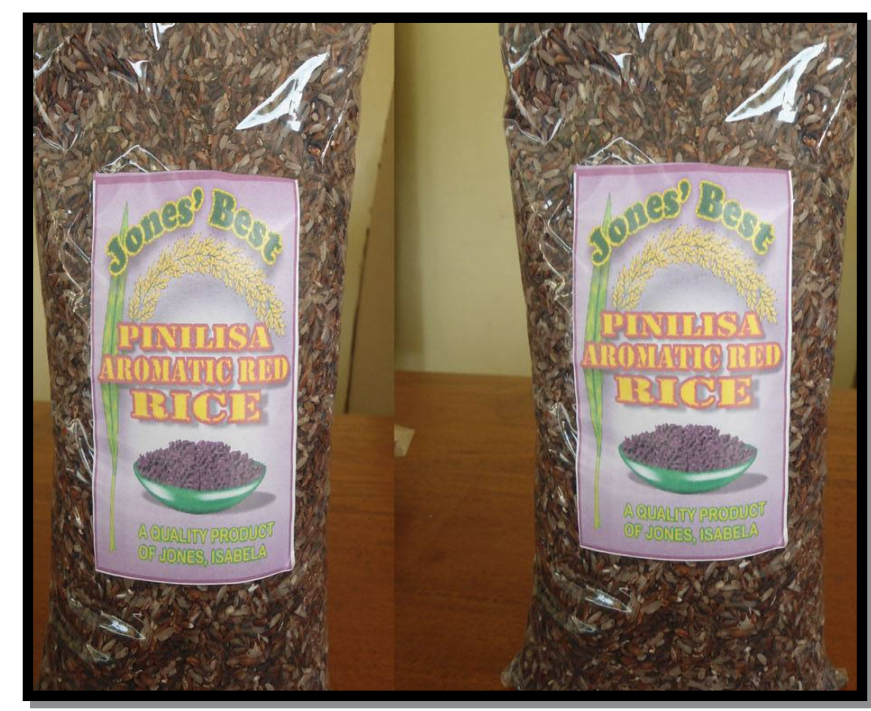

Fig. 1. a) Pinilisa is known for its aroma and red color. It is a long grain, tall and late-maturing rice cultivar (Photo credit to LGU-DA, Jones, Isabela).

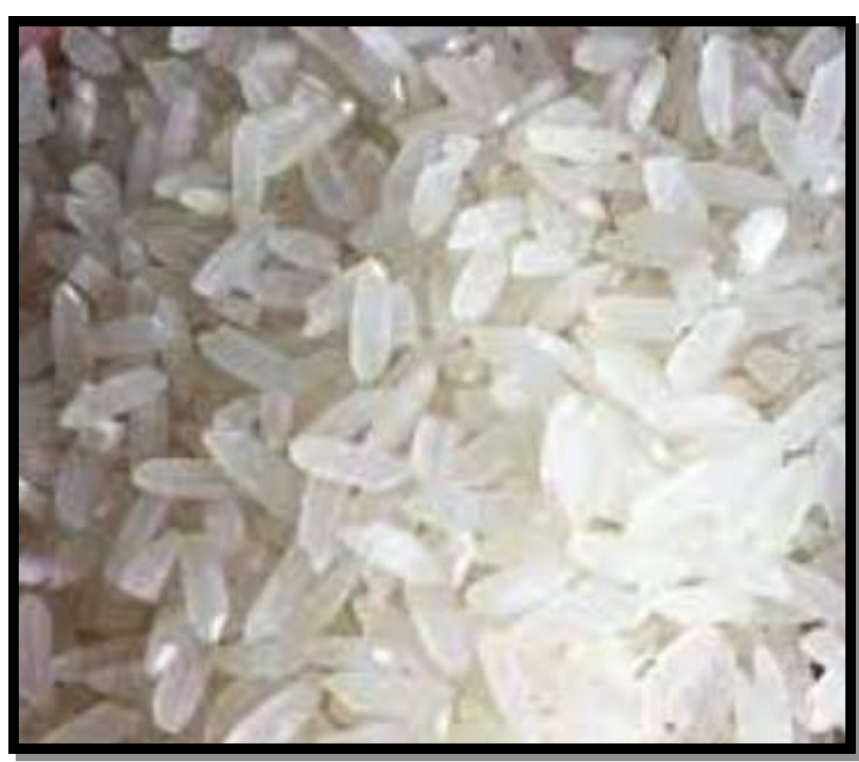

Fig. 1. b) Palawan is a white-colored, medium-sized grain, tall and late maturing rice cultivar. 


\section{Materials and Methods}

\section{Study area}

The study was conducted in the experimental area of the Isabela State University, Jones Campus for one cropping season only. A total of $563.75 \mathrm{~m}^{2}$ composed of 36 plots was utilized in this study. The area was plowed and pulverized once with a hand tractor. The experimental area was divided into 3 equal blocks and further subdivided into 12 plots per block representing the 6 treatments. An alleyway of $50 \mathrm{~cm}$ was constructed between each plot and 1 meter between each block (Fig. 2).

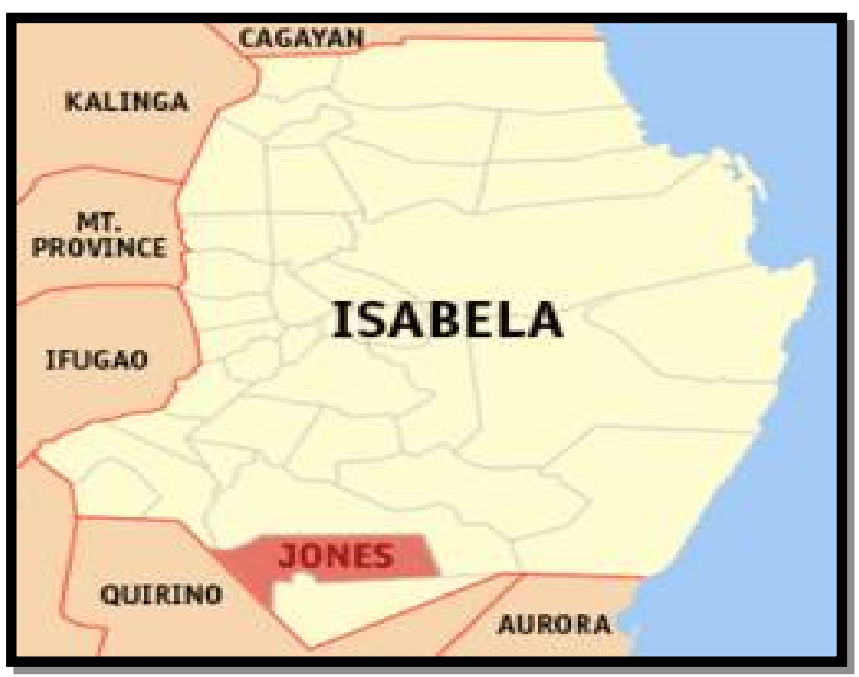

Fig. 2. Location of the study area (Image source: en.wikipedia.org).

\section{Seeding and seeding rate}

Upland rice (Pinilisa and Palawan) seeds were sown in the prepared field by drilling with a depth of $2-3 \mathrm{~cm}$.

\section{Application of seaweed extract and fertilizer}

Seaweed extract was applied at 1) early vegetative stage, 2) maximum tillering to panicle initiation and 3) before flowering stage of the upland rice. It was applied to V1F4, V1F5, V1F6, V2F4, V2F5 and V2F6, respectively at $3 \mathrm{~L}$ per application per ha. The recommended fertilizer per ha based on soil analysis was 40-10-0 kg NPK ha-1. Basal fertilizer was placed in the furrows covered with thin soil before planting. The second application of recommended inorganic fertilizer was placed near the base of the plants and it was covered through the utilization of plowing.

\section{Care and maintenance of the crop}

Manual weeding was done as soon as the weeds emerged in the area. Weeding was employed to avoid nutrient, sunlight and water competition on the rice plants. Weed competition is typically one of the major problems in upland rice leading to significant yield losses and sometimes to complete crop failure, thereby threatening the food security of subsistence farmers (23).

Regular monitoring of the area was done and the occurrence of pests and diseases were minimized by proper sanitation and application of recommended pesticide following the manufacturer's recommendation. Artificial irrigation early in the morning was applied in the absence of rainfall to supply the moisture requirements of the crop.

\section{Experimental design and treatments}

The different treatments were randomly assigned in their respective plot using Randomized Blocks in Factorial Scheme with 6 treatments and replicated thrice. The treatments are as follows: Factor A: Pinilisa (V1) and Palawan (V2); and Factor B: F1-150-100 kg NP $\mathrm{ha}^{-1}$ (Farmer's Practice), F2-40-10 kg NP ha-1 (100\% Recommended Rate), F3-20-5 kg NP ha ${ }^{-1}$ (50\% Recommended Rate), F4-40-10 kg NP ha-1 +3 L/ha. seaweed extract, F5-20-5 kg NP ha-1 +3 L/ha. seaweed extract and F6-3 L/ha. seaweed extract.

\section{Data collection}

The growth and yield parameters gathered such as plant height, number of productive and unproductive tillers, length of panicle, number of filled and unfilled grains per panicle, weight of 1000 grains, grain yield and straw yield are studied. Thirty representative sample plants per plot were randomly selected and they were labeled properly using pegs.

Table 1. Principal Component Analysis $\left(6 \mathrm{~m}^{2}\right)$

\begin{tabular}{|c|c|c|c|c|c|c|c|c|c|c|c|}
\hline Statistics & PC1 & PC2 & PC3 & PC4 & PC5 & PC6 & PC7 & PC8 & PC9 & PC10 & PC11 \\
\hline Standard deviation & 2.0102 & 1.7767 & 1.2092 & 0.8879 & 0.7854 & 0.7005 & 0.5243 & 0.3462 & 0.1713 & 0.1291 & 0.0610 \\
\hline Proportion of Variance & 0.3674 & 0.2870 & 0.1329 & 0.0717 & 0.0561 & 0.0446 & 0.0250 & 0.0109 & 0.0027 & 0.0015 & 0.0003 \\
\hline Cumulative Proportion & 0.3674 & 0.6543 & 0.7872 & 0.8589 & 0.9150 & 0.9596 & 0.9846 & 0.9955 & 0.9981 & 0.9997 & 1.0000 \\
\hline EigenValues & 4.0411 & 3.1566 & 1.4621 & 0.7883 & 0.6169 & 0.4907 & 0.2749 & 0.1198 & 0.0294 & 0.0167 & 0.0037 \\
\hline \multicolumn{12}{|l|}{ EIGENVECTORS } \\
\hline Variables & PC1 & PC2 & PC3 & PC4 & PC5 & PC6 & PC7 & PC8 & PC9 & PC10 & PC11 \\
\hline Plant Height at 30 DAP & 0.2543 & -0.2707 & 0.5136 & -0.0019 & 0.1453 & -0.4212 & 0.2345 & -0.1139 & 0.3663 & -0.1168 & 0.4289 \\
\hline Plant Height at 60 DAP & 0.4425 & -0.0060 & -0.0623 & -0.2619 & 0.1764 & 0.3821 & -0.2890 & -0.5056 & 0.2696 & 0.3775 & 0.0191 \\
\hline Plant Height at 90 DAP & 0.4452 & 0.0845 & -0.0519 & 0.2898 & 0.3115 & 0.1107 & 0.3648 & 0.0075 & 0.1376 & -0.3664 & -0.5589 \\
\hline Plant Height at Maturity & 0.3932 & 0.2869 & -0.0929 & 0.2228 & 0.1939 & 0.0157 & 0.2750 & 0.3096 & -0.3771 & 0.4513 & 0.3868 \\
\hline Productive Tillers & 0.2165 & 0.4194 & 0.0259 & -0.0182 & -0.6122 & -0.0896 & -0.0034 & 0.2965 & 0.5229 & 0.1475 & -0.1011 \\
\hline Unproductive Tillers & -0.2306 & -0.1532 & -0.5929 & 0.4634 & 0.1796 & -0.0210 & -0.0048 & 0.0058 & 0.5007 & 0.0621 & 0.2640 \\
\hline Panicle Length & -0.0503 & 0.4316 & 0.3095 & 0.2416 & 0.3969 & -0.0012 & -0.6411 & 0.1962 & 0.0855 & -0.1926 & 0.0742 \\
\hline Filled Grains & -0.0936 & 0.4405 & -0.2389 & -0.5203 & 0.1615 & 0.1698 & 0.2748 & -0.0206 & 0.1058 & -0.4422 & 0.3630 \\
\hline Grain Yield & -0.2403 & 0.3736 & -0.0462 & -0.1411 & 0.2965 & -0.5718 & 0.1538 & -0.2853 & 0.0572 & 0.3745 & -0.3147 \\
\hline 1.000 Filled Grains & 0.3765 & 0.1048 & -0.3603 & 0.1257 & -0.2655 & -0.4612 & -0.2854 & -0.3627 & -0.2868 & -0.3269 & 0.1276 \\
\hline Straw Yield & -0.2755 & 0.3270 & 0.2898 & 0.4668 & -0.2530 & 0.2951 & 0.2472 & -0.5438 & -0.0614 & -0.0245 & 0.1456 \\
\hline
\end{tabular}


Table 2. Plant height at 30 and 60 days after planting and at maturity of upland rice as influenced by inorganic fertilizer and seaweed extract $\left(6 \mathrm{~m}^{2}\right)$

\begin{tabular}{|c|c|c|c|c|}
\hline Treatments & $\begin{array}{c}\text { 30 Days } \\
\text { After } \\
\text { Planting }\end{array}$ & $\begin{array}{l}60 \text { Days } \\
\text { After } \\
\text { Planting }\end{array}$ & $\begin{array}{c}90 \text { Days } \\
\text { After } \\
\text { Planting }\end{array}$ & $\underset{\text { Maturity }}{\text { At }}$ \\
\hline \multicolumn{5}{|l|}{ FACTOR A } \\
\hline V1 & 8.64 & $47.86^{\mathrm{b}}$ & $68.90^{\mathrm{b}}$ & $76.14^{\mathrm{b}}$ \\
\hline $\mathrm{V} 2$ & 9.24 & $57.72^{a}$ & $80.44^{a}$ & $86.33^{a}$ \\
\hline ANOVA & ns & $* *$ & $* *$ & $*$ \\
\hline \multicolumn{5}{|l|}{ FACTOR B } \\
\hline $\mathrm{F} 1$ & 9.40 & $56.96^{\mathrm{a}}$ & 75.97 & 79.66 \\
\hline $\mathrm{F} 2$ & 9.41 & $48.63^{\mathrm{b}}$ & 69.76 & 73.59 \\
\hline F3 & 8.68 & $53.31^{\mathrm{ab}}$ & 74.77 & 78.95 \\
\hline $\mathrm{F} 4$ & 9.21 & $51.27^{\mathrm{ab}}$ & 79.71 & 86.29 \\
\hline F5 & 8.71 & $53.73^{\mathrm{ab}}$ & 75.49 & 85.85 \\
\hline F6 & 8.24 & $52.87^{\mathrm{ab}}$ & 72.35 & 83.07 \\
\hline ANOVA & ns & $*$ & ns & ns \\
\hline \multicolumn{5}{|c|}{ FACTOR A x B } \\
\hline V1BF1 & 9.20 & 48.95 & 68.67 & 73.83 \\
\hline V1F2 & 9.20 & 45.96 & 69.77 & 73.41 \\
\hline V1F3 & 7.63 & 48.60 & 69.39 & 73.23 \\
\hline V1F4 & 8.93 & 45.02 & 66.20 & 73.86 \\
\hline V1F5 & 8.59 & 48.59 & 74.22 & 87.18 \\
\hline V1F6 & 8.31 & 50.06 & 65.18 & 75.31 \\
\hline V2F1 & 9.59 & 64.97 & 83.26 & 85.48 \\
\hline $\mathrm{V} 2 \mathrm{~F} 2$ & 9.62 & 51.30 & 69.75 & 73.77 \\
\hline V2F3 & 9.73 & 58.01 & 80.15 & 84.66 \\
\hline V2F4 & 9.48 & 57.51 & 93.21 & 98.72 \\
\hline V2F5 & 8.83 & 58.87 & 76.75 & 84.51 \\
\hline V2F6 & 8.16 & 55.68 & 79.52 & 90.82 \\
\hline ANOVA & $\mathrm{ns}$ & ns & ns & ns \\
\hline C.V (\%) & 12.73 & 7.64 & 13.41 & 13.74 \\
\hline
\end{tabular}

ns =not significant, ${ }^{*}=$ significant, ${ }^{* *}=$ highly significant

Note: Values with common letter in the same column are not significantly different in the DMRT test at 5\% level.

\section{Harvesting, drying and threshing}

Upland rice cultivars were harvested 152 days after planting when $80 \%$ of the grains reached physiological maturity. Manual harvesting was done using a scythe. Sun-drying was done after threshing to reduce the moisture content. Threshing was done manually. The harvested samples were individually packed then properly labeled to avoid intermixing of grains.

\section{Economic analysis}

Economic analysis was performed by subtracting the estimated gross profits from the projected actual cost of production.

\section{Statistical analysis}

All gathered data were recorded, tabulated and analyzed using the Analysis of Variance for Randomized Blocks in a Factorial Scheme. The treatments with significant results were compared using the Duncan's Multiple Range Test (DMRT) at a $5 \%$ level.

\section{Results and Discussion}

Plant height at 30, 60, 90 days after planting and at maturity. Table 2 presents the plant height of upland rice varieties at 30,60 and 90 days after planting and at maturity. Analysis of Variance (ANOVA) revealed no significant $(\mathrm{P}>0.05)$ result at 30 days after planting on Factor A (Upland Rice Varieties), Factor B (Fertilizers) and Factor A x B (Upland Rice Varieties and Fertilizers). However, at 60 days after planting, Analysis of Variance (ANOVA) revealed a highly significant $(\mathrm{P}<0.001)$ result. The Palawan (V2) obtained the tallest height which is significantly different from Pinilisa (V1). The application of fertilizer levels (Factor B) revealed a significant $(\mathrm{P}<0.05)$ result. Application of farmer's practice obtained the tallest height at 60 days after planting among the treatments which are comparable to plants applied with 20-5 $\mathrm{kg} \mathrm{NP} \mathrm{ha}^{-1}+$

Table 3. Number of productive tillers, unproductive tillers, filled and unfilled grains of upland rice cultivars as influenced by inorganic fertilizer and seaweed extract $\left(6 \mathrm{~m}^{2}\right)$

\begin{tabular}{|c|c|c|c|c|}
\hline Treatments & $\begin{array}{c}\text { Productive } \\
\text { Tillers }\end{array}$ & $\begin{array}{c}\text { Unproductiv } \\
\text { e Tillers }\end{array}$ & $\begin{array}{c}\text { Number of } \\
\text { Filled Grains }\end{array}$ & $\begin{array}{c}\text { Number of } \\
\text { Unfilled Grains }\end{array}$ \\
\hline \multicolumn{5}{|l|}{ FACTOR A } \\
\hline V1 & $1.69^{b}$ & $0.86^{\mathrm{a}}$ & 70.54 & $41.77^{a}$ \\
\hline $\mathrm{V} 2$ & $1.87^{\mathrm{a}}$ & $0.60^{\mathrm{b}}$ & 62.61 & $31.84^{\mathrm{b}}$ \\
\hline ANOVA & $* *$ & $* *$ & ns & $* *$ \\
\hline \multicolumn{5}{|l|}{ FACTOR B } \\
\hline $\mathrm{F} 1$ & 1.64 & 0.46 & $69.26^{\mathrm{ab}}$ & $41.11^{\mathrm{a}}$ \\
\hline $\mathrm{F} 2$ & 1.58 & 0.88 & $52.23^{\mathrm{b}}$ & $42.72^{\mathrm{a}}$ \\
\hline F3 & 1.78 & 1.06 & $61.58^{\mathrm{ab}}$ & $38.30^{\mathrm{ab}}$ \\
\hline $\mathrm{F} 4$ & 1.78 & 0.61 & $61.21^{\mathrm{ab}}$ & $38.50^{\mathrm{ab}}$ \\
\hline F5 & 1.98 & 0.70 & $76.64^{\mathrm{a}}$ & $31.49^{\mathrm{ab}}$ \\
\hline F6 & 1.92 & 0.66 & $78.24^{\mathrm{a}}$ & $28.73^{b}$ \\
\hline ANOVA & ns & ns & $* *$ & $* *$ \\
\hline \multicolumn{5}{|c|}{ Factor A x B } \\
\hline V1BF1 & $1.66^{\mathrm{ab}}$ & $0.44^{\mathrm{b}}$ & 76.87 & 46.61 \\
\hline V1F2 & $1.28^{\mathrm{c}}$ & $1.28^{\mathrm{a}}$ & 52.88 & 49.00 \\
\hline V1F3 & $1.53^{\mathrm{bc}}$ & $1.53^{\mathrm{a}}$ & 71.33 & 36.12 \\
\hline V1F4 & $1.82^{\mathrm{ab}}$ & $0.61^{\mathrm{b}}$ & 55.70 & 43.66 \\
\hline V1F5 & $2.00^{\mathrm{a}}$ & $0.73^{b}$ & 83.32 & 39.32 \\
\hline V1F6 & $1.85^{\mathrm{ab}}$ & $0.57^{b}$ & 82.52 & 35.91 \\
\hline V2F1 & $1.61^{\mathrm{b}}$ & $0.48^{\mathrm{b}}$ & 61.64 & 35.61 \\
\hline V2F2 & $1.88^{\mathrm{ab}}$ & $0.49^{\mathrm{a}}$ & 51.58 & 36.43 \\
\hline V2F3 & $1.74^{\mathrm{ab}}$ & $0.58^{\mathrm{a}}$ & 51.83 & 40.47 \\
\hline V2F4 & $2.05^{\mathrm{a}}$ & $0.61^{\mathrm{a}}$ & 66.71 & 33.34 \\
\hline V2F5 & $1.95^{\mathrm{ab}}$ & $0.67^{\mathrm{a}}$ & 69.95 & 23.65 \\
\hline V2F6 & $1.99^{\mathrm{a}}$ & $0.74^{\mathrm{a}}$ & 73.96 & 21.54 \\
\hline ANOVA & $* *$ & $* *$ & ns & ns \\
\hline C.V. (\%) & 7.99 & 20.96 & 17.28 & 18.02 \\
\hline
\end{tabular}

3L/ha. seaweed extract (F5), 20-5 kg NP ha-1 (F3), 3L/ ha. seaweed extract (F6) and 40-10 kg NP ha-1 + $3 \mathrm{~L} / \mathrm{ha}$ (F4). The result was similar to an earlier study conducted which revealed that the use of enhancedefficiency $\mathrm{N}$ sources increased the productivity and plant height of upland rice crop (24). At 90 days after planting and at maturity, the same pattern of no significant results was obtained. Generally, the superiority of Palawan (V2) in terms of heights from 60 days after planting until maturity is attributed to the genetic characteristics of the plants. Consistently, such variety got the tallest height and showed differences with the Pinilisa cultivar. The data means that the upland rice applied with inorganic fertilizer combined with seaweed extract 
have statistically the same plant height at maturity (control and different levels of inorganic fertilizer and seaweed extract).

The difference in the plant height averages of cultivars tested was due to genetic differences (25). The differences in plant height were determined more by genetic factors. In addition to being influenced by genetic factors, plant height was also influenced by environmental growth conditions (26). Furthermore, it was stated that plant height was highly associated with lodging and ease of harvest, so it was one of the important characteristics that influence the levels of acceptance of new cultivars by farmers (27). Nitrogen fertilizer is an important plant nutrient for plant growth and yield and application of this nutrient significantly affected the height of the plants, biomass and yield (28). The application of seaweed extract combined with amino acids could increase the height of plants (29).

\section{Number of productive and unproductive tillers}

As shown in Table 3 , the rice cultivars as a single factor affected the number of productive tillers per plant wherein the Palawan (V2) produced the most number of productive tillers compared to the Pinilisa (V1). However, the different levels of fertilizer used in the study did not affect the number of productive tillers. The result implies that the reduction of fertilizer application can result to low tiller production. The result obtained was in contrast to the research conducted earlier (30), that increased application of nitrogen contributes to the production of tillers and to the another study performed stating that application of seaweed extract can increase the production of more tillers in rice plants (14). The variety and fertilizer as the two factors combination affected the number of productive tillers. The different levels of inorganic fertilizer and seaweed extract as combined factors revealed a highly significant result in terms of number of productive and unproductive tillers. The Pinilisa cultivar applied with $20-10-0 \mathrm{~kg} \mathrm{NP}+3 \mathrm{~L}$ of seaweed extract (V1 x F5) as well as Palawan cultivar applied with fertilizer at the rate of $40-10-0 \mathrm{~kg} \mathrm{NP}+3 \mathrm{~L}$ seaweed extract (V2 $\mathrm{x}$ F4) produced the most number of productive tillers. On the other hand, the Pinilisa cultivar applied with 20-5 kg NP ha-1 (50\% Recommended Rate) and 40-10 kg NP ha ${ }^{-1}$ (100\% Recommended Rate) obtained the most number of unproductive tillers and the Palawan cultivar applied with $3 \mathrm{~L}$ seaweed extract alone (V2F6) produced the most number of tillers without panicles. The application of reduced nitrogen fertilizer on rice may cause tiller abortion.

Likewise, the upland rice cultivars as an independent factor influenced the number of unproductive tillers. The result was similar to the earlier research report that the plant hormones in seaweed extract and organic fertilizer can initiate and encourage growth of rice plant such as tiller and the other rice plant structures $(31,32)$. Tillering ability is one of the most important traits of the rice crop because it plays a major role in grain yield determination that a further increase in rice yield potential may be impossible by unproductive tillers reduction or elimination (19).

\section{Number of filled and unfilled grains}

Variation did not exist in terms of the number of filled grains produced by the upland rice varieties as a single factor. A trend of a significant increase in the number of filled grains was observed with the levels of fertilizer and seaweed extract as independent factors. Plants applied with 3L seaweed extract (F6) obtained the highest number of filled grains which are comparable to the plants applied with 20-5 kg NP ha-1 $+3 \mathrm{~L} /$ ha. seaweed extract (F5), Farmer's Practice (F1), 20-5 kg NP ha-1 (F3) and 40-10 kg NP ha ${ }^{-1}+3 \mathrm{~L} / \mathrm{ha}$. seaweed extract (F4). These results indicated that upland rice cultivars have a greater filled grains potential at lower rates of fertilizer. It seems that the appropriate level for upland rice varieties is lower under current conditions. However, there is no significant result in terms of number of filled grains by the application of seaweed extract and different fertilizer levels in upland rice cultivars.

The upland rice cultivars as a single factor affected the number of unfilled grains of Pinilisa (V1) which produced the most filled grains compared to the Palawan (V2). A significant increase in the number of unfilled grains existed by the plants fertilized with $100 \%$ RR (F2). Such treatment is comparable to the plants fertilized following the Farmer's Practice (F1), F4 (100\% RR + 3 L seaweed extract), F3 (50 \% RR) and F5 (50\% RR + 3 L seaweed extract). Plants sprayed with $3 \mathrm{~L}$ seaweed extract attained the least number of unfilled grains. This suggests that the Pinilisa (V1) might be more sensitive to levels of nitrogen than the Palawan (V2), thus manufactured more unfilled grains. Not significant result $(\mathrm{P}>0.05)$ was observed between cultivar and fertilizer management in terms of the number of unfilled grains. This implies that the application of different levels of inorganic fertilizer combined with $3 \mathrm{~L}$ seaweed extract can increase the number of unfilled rice grains. The study result was in contrast with the research conducted earlier, the application of fertilizer improves various crop parameters like more filled grains thus, resulting in higher grain yields (24).

\section{Length of panicle}

The length of the upland rice panicle was presented in Table 4 column 2 . The varieties used as a single factor were not affected by panicle length with a mean ranging between $18.82 \mathrm{~cm}$ to $19.54 \mathrm{~cm}$. Similarly, the fertilizer as another factor did not tend to increase the length of the panicle with a mean ranging from 17.59 $\mathrm{cm}$ to $20.44 \mathrm{~cm}$. The interaction of fertilizer and variety revealed a not significant $(\mathrm{P}>0.05)$ result with a mean ranging between $16.95 \mathrm{~cm}$ to $21.40 \mathrm{~cm}$. However, in a study it was reported that the interaction between upland rice varieties and fertilization practices obtained longer panicle (33).

\section{Weight of $\mathbf{1 0 0 0}$ filled grains}

The application of inorganic fertilizer and seaweed extract can increase significantly the weight of two upland rice cultivars used in the study. Palawan cultivar (V2) gained the heaviest 1000 filled grains 
Table 4. Length of panicle, weight of 1000 filled grains, grain yield and straw yield of upland rice as influenced by inorganic fertilizer and seaweed extract $\left(6 \mathrm{~m}^{2}\right)$

\begin{tabular}{|c|c|c|c|c|}
\hline $\begin{array}{c}\text { Treatme } \\
\text { nts }\end{array}$ & $\begin{array}{l}\text { Panicle } \\
\text { Length } \\
\text { (cm) }\end{array}$ & $\begin{array}{l}\text { Weight of } 1000 \\
\text { Filled Grains } \\
\text { (g) }\end{array}$ & $\begin{array}{l}\text { Grain } \\
\text { Yield } \\
\text { (t/ha) }\end{array}$ & $\begin{array}{c}\text { Straw } \\
\text { Yield } \\
\text { (kg/ha) }\end{array}$ \\
\hline \multicolumn{5}{|l|}{ FACTOR A } \\
\hline V1 & 19.54 & $18.74^{\mathrm{b}}$ & $0.96^{\mathrm{a}}$ & $2.20^{\mathrm{a}}$ \\
\hline V2 & 18.82 & $21.55^{\mathrm{a}}$ & $0.80^{\mathrm{b}}$ & $1.89^{b}$ \\
\hline ANOVA & ns & $* *$ & ** & * \\
\hline \multicolumn{5}{|l|}{ FACTOR B } \\
\hline F1 & 19.07 & 18.68 & 0.86 & 1.88 \\
\hline F2 & 17.59 & 19.62 & 0.83 & 1.90 \\
\hline F3 & 18.69 & 20.33 & 0.80 & 1.84 \\
\hline F4 & 20.44 & 19.63 & 0.89 & 2.46 \\
\hline F5 & 19.88 & 21.95 & 1.01 & 2.02 \\
\hline F6 & 19.43 & 19.99 & 0.90 & 2.16 \\
\hline ANOVA & ns & ns & ns & ns \\
\hline \multicolumn{5}{|c|}{ FACTOR A x B } \\
\hline V1F1 & 19.06 & 17.73 & 0.97 & 1.93 \\
\hline V1F2 & 18.23 & 19.10 & 0.92 & 1.75 \\
\hline V1F3 & 18.21 & 19.27 & 0.88 & 2.19 \\
\hline V1F4 & 21.40 & 17.87 & 0.93 & 2.72 \\
\hline V1F5 & 20.49 & 19.80 & 1.09 & 2.26 \\
\hline V1F6 & 19.86 & 18.67 & 0.97 & 2.34 \\
\hline V2F1 & 19.07 & 19.63 & 0.75 & 1.83 \\
\hline V2F2 & 16.95 & 20.13 & 0.74 & 2.05 \\
\hline V2F3 & 19.16 & 21.39 & 0.71 & 1.49 \\
\hline V2F4 & 19.47 & 22.73 & 0.85 & 2.20 \\
\hline V2F5 & 19.26 & 24.10 & 0.93 & 1.78 \\
\hline V2F6 & 19.00 & 21.30 & 0.83 & 1.97 \\
\hline ANOVA & ns & ns & ns & ns \\
\hline C.V. (\%) & 7.97 & 9.14 & 19.26 & 21.93 \\
\hline
\end{tabular}

**-highly significant, *-significant, ns-not significant

Note: Values with common letter in the same column are not significantly different in the DMRT test at 5\% level.

which is significantly higher over Pinilisa cultivar (V1). However, the interaction effect of fertilizer and variety and the combination of two factors on the 1000 grain weight was not significant (Table 4 column 3 ). The result implies that different levels of inorganic fertilizer and seaweed extract have the same weight of 1000 filled grains applied with farmers practice as the control and different fertilizer levels combined with seaweed extract.

\section{Grain yield}

A highly significant result $(\mathrm{P}<0.001)$ was obtained in which Pinilisa (V1) obtained the highest yield which is significantly different from Palawan (V2). Likewise, a highly significant result $(\mathrm{P}<0.001)$ was obtained with regard to fertilizer management. This result signifies that the different levels of inorganic fertilizer and seaweed extract can increase the yield of upland rice. However, fertilizer and variety interactions demonstrated a not significant result $(\mathrm{P}>0.05)$ as presented in Table 4 column 4.

The result was comparable to the research (34), who highlighted facts that the yield components affected by the application of inorganic fertilizers alone and using the combination of farmyard manure and inorganic fertilizers significantly produced more number of tillers per hill, number of panicle per hill and number of grain per panicle when compared to the treatments with no fertilizer applied and using farmyard manure alone. Moreover, (35) evaluated facts that substantial responses of rice to nitrogen and phosphorus fertilization increased significantly on grain yield, number of panicle $/ \mathrm{m}^{2}$, number of tiller/plant, number of tiller $/ \mathrm{m}^{2}$ and plant height. The result is likewise similar to the study conducted reporting that foliar

Table 5. Economic analysis of using inorganic fertilizer and seaweed extract

\begin{tabular}{cccccc}
\hline Treatments & $\begin{array}{c}\text { Gross } \\
\text { Income } \\
\text { (Php) }\end{array}$ & $\begin{array}{c}\text { Yield } \\
\text { (kg/ha) }\end{array}$ & $\begin{array}{c}\text { Total } \\
\text { Cost } \\
\text { (Php) }\end{array}$ & $\begin{array}{c}\text { Net } \\
\text { Income } \\
\text { (Php) }\end{array}$ & ROI (\%) \\
\hline V1F1 & 46,560 & 970 & 28,680 & 17,880 & 62.34 \\
\hline V1F2 & 44,160 & 920 & 29,805 & 14,355 & 48.16 \\
\hline V1F3 & 42,240 & 880 & 26,304 & 15,936 & 60.58 \\
\hline V1F4 & 44,640 & 930 & 33,435 & 11,205 & 33.51 \\
\hline V1F5 & 52,320 & 1090 & 29,370 & 22,950 & 78.14 \\
\hline V1F6 & 46,560 & 970 & 23,820 & 22,740 & 95.47 \\
\hline V2F1 & 20,250 & 750 & 26,915 & $-6,665$ & -24.76 \\
\hline V2F2 & 19,980 & 740 & 29,262 & $-9,282$ & -31.72 \\
\hline V2F3 & 19,170 & 710 & 26,324 & $-7,154$ & -27.18 \\
\hline V2F4 & 22,950 & 850 & 30,869 & $-7,919$ & -25.65 \\
\hline V2F5 & 25,110 & 930 & 27,713 & $-2,603$ & -9.39 \\
\hline V2F6 & 22,410 & 830 & 23,516 & $-1,106$ & -4.70 \\
\hline & & & & &
\end{tabular}

spray of seaweed extract and application of inorganic fertilizer significantly increased plant height, dry matter accumulation, chlorophyll index, crop growth rate, yield attributes and yield of rice (36). Thus, it is an important option to increase yield and quality of rice and sustaining soil fertility.

\section{Straw yield}

Straw yield increased significantly with an increment of inorganic fertilizer levels and $3 \mathrm{~L}$ seaweed extract (Table 4 column 5). As a single factor, the varietal difference for straw yield was significant in which Pinilisa cultivar had a heavier straw yield of 2.20 tons over Palawan with 1.89 tons per hectare. Irrespective of the levels of fertilizer, the two rice cultivars were not responsive. However, the interaction of both factors resulted in a significant increase in the straw yield of rice. The result implies that the application of different levels of inorganic fertilizer and $3 \mathrm{~L}$ seaweed extract can contribute to the increase of straw yield of rice. Straw yield is affected by the concentration of nutrients. The application of seaweed extract on rice can promote the nutrient absorption in the leaves thus, increasing the weight of rice straw. The result was similar to the research conducted stating that the application of organic and inorganic fertilizer $(50 \% \mathrm{NPK}$ and vermicompost) can significantly produce higher straw yield than the other treatments used (37).

\section{Economic analysis}

The estimated economic analysis is shown in Table 5. It indicates that Pinilisa (V1) applied with 3 liters seaweed extract gained the highest return on investment with $95.47 \%$ while Palawan (V2) applied with 100\% 
recommended rate gained the lowest return on investment.

\section{Conclusion}

Based on the study result, the Pinilisa cultivar (V1) obtained a higher yield compared to the Palawan cultivar (V2). The combination of seaweed extract and different levels of inorganic fertilizer application shows highly significant differences especially concerning the number of productive tillers, filled grains, 1000 grain weight, and straw weight of upland rice. Seaweed extract as foliar fertilizer can be applied not only in rice but also in other crops. The combination of seaweed extract and inorganic fertilizer is recommended in upland rice to obtain a higher yield. This is a potentially integrated crop management modality in upland rice production hence, it is recommended. However, among the fertilizer combinations, $3 \mathrm{~L}$ of seaweed extract per ha gained the highest return on investment (ROI). Confirmation of the result of this study be conducted through a follow-up study is recommended to come up with more conclusive results.

\section{Acknowledgements}

The researcher wishes to acknowledge Dr. Lucila V. Rocha, for the technical support, Ms. Frances Marie Antonette A. Duran and Mr. Jayson C. Sebastian for their valuable contributions in the data gathering and analysis.

\section{Compliance with ethical standards}

Conflict of interest: The author declares that the provided information has no conflict of interest.

Ethical issues: None.

\section{References}

1. Portilla JC, Mirandilla JR. Documentation of indigenous practices in upland (traditional) rice production areas and site characterization in CAR [Cordillera Administrative Region, Philippines]. Philippine Journal of Crop Science (Philippines). 2013.

2. Nguyen NT, Pham CV, Nguyen DT, Mochizuki T. Genotypic variation in morphological and physiological characteristics of rice (Oryza sativa L.) under aerobic conditions. Plant Production Science. 2015;18(4). http://doi.org/10.1626/pps.18.501

3. Atlin GN, Lafitte HR, Tao D, Laza M, Amante M, Courtois B. Developing rice cultivars for high-fertility upland systems in the Asian tropics. Field Crops Research. 2006;97(1):43-52. http:// doi.org/10.1016/j.fcr.2005.08.014

4. Leghari SJ, Wahocho NA, Laghari GM, HafeezLaghari A, MustafaBhabhan G, HussainTalpur K, Bhutto TA, Wahocho SA, Lashari AA. Role of nitrogen for plant growth and development: A review. Advances in Environmental Biology. 2016 Sep 1;10(9):209-19.

5. Lea PJ, Miflin BJ. Nitrogen assimilation and its relevance to crop improvement, nitrogen metabolism in plants in the post-genomic era. Annu. Plant Rev. 2011;42:1-40.

6. Philippine Statistics Authority. Region 02; 2019.

7. PhilRice-Isabela, Philippine Rice R\&D Highlights 2012. PhilRice. 2012 https://philrice.gov.ph/wp-content/uploads/2015/05/2012_Isabela.pdf
8. Layek J, Das A, Ramkrushna G, Trivedi K, Yesuraj D, Chandramohan M, Kubavat D, Agarwal P, Ghosh A. Seaweed sap: a sustainable way to improve productivity of maize in North-East India. International Journal of Environmental Studies. 2015;72(2):305-11. http://doi.org/10.1080/00207233.2015.1010855

9. Tsujimoto Y, Rakotoson T, Tanaka A, Saito K. Challenges and opportunities for improving $\mathrm{N}$ use efficiency for rice production in sub-Saharan Africa. Journal Plant Production Science. 2019;22(4). https://doi.org/10.1080/1343943X.2019.1617638

10. Liu H, Zhan J, Hussain S, Nie L. Grain yield and resource use efficiencies of upland and lowland rice cultivars under aerobic cultivation. Agronomy. 2019;9(10):591. https://doi.org/10.3390/ agronomy 9100591

11. Liu Q, Ma H, Lin X ' Zhou X, Zhao Q. Effects of different types of fertilizers application on rice grain quality. Chilean Journal of Agricultural Research. 2019;79(2). http://dx.doi.org/10.4067/ S0718-58392019000200202

12. Singh B. Singh V. Fertilizer Management in Rice. In: Chauhan B., Jabran K., Mahajan G. (eds) Rice Production Worldwide. Springer, Cham. 2017. https://doi.org/10.1007/978-3-319-475165_10

13. Pramanick B, Brahmachari K, Kar S, Mahapatra B S. Can foliar application of seaweed sap improve the quality of rice grown under rice-potato-greengram crop sequence with better efficiency of the system? Journal of Applied Phycology. 2020;32:3377-86. https://doi.org/10.1007/s10811-020-02150-Z

14. Sunarpi JA, Kurnianingsih R, Julisaniah, NI, Nikmatullah A. Effect of seaweed extracts on growth and yield of rice plants. Nusantara Bioscience. 2010;2(2). http://doi.org/10.13057/nusbiosci/n020204

15. Rathore S, Chaudhary D, Boricha G, Ghosh A, Bhatt B, Zodape S, Patolia J. Effect of seaweed extract on the growth, yield and nutrient uptake of soybean (Glycine max) under rainfed conditions. South African Journal of Botany. 2009;75(2):351-55. https://doi.org/10.1016/j.sajb.2008.10.009

16. Mishra A, Sahni S, Kumar S, Prasad. BD. Seaweed - An ecofriendly alternative of agrochemicals in sustainable agriculture. Current Journal of Applied Science and Technology. 2020;39(27):71-78. https://doi.org/10.9734/cjast/2020/v39i2730921

17. Mahmoud S, Salama D, El-Tanahy A, El-Samad E. Utilization of seaweed (Sargassum vulgare) extract to enhance growth, yield and nutritional quality of red radish plants. Annals of Agricultural Sciences. 2019;64(2):167-75. https://doi.org/10.1016/ j.aoas.2019.11.002

18. Al-Juthery HW, Drebee HA, Al-Khafaji BM, Hadi RF. Plant Biostimulants, Seaweeds Extract as a Model (Article Review). InIOP Conference Series: Earth and Environmental Science 2020 Aug 1 (Vol. 553, No. 1, p. 012015). IOP Publishing. http://doi.org/ 10.1088/1755-1315/553/1/012015

19. Zewail RM. Effect of seaweed extract and amino acids on growth and productivity and some biocostituents of common bean (Phaseolus vulgaris L) plants. Journal of Plant Production. 2014 Aug 1;5(8):1441-53. http://doi.org/10.21608/jpp.2014.64669

20. Yao Y, Wang X, Chen B, Zhang M, Ma J. Seaweed extract improved yields, leaf photosynthesis, ripening time, and net returns of tomato (Solanum lycopersicum Mill.). ACS omega. 2020 Feb 21;5(8):4242-9. http://doi.org/10.1021/acsomega.9b04155

21. Arioli T, Mattner SW, Winberg PC. Applications of seaweed extracts in Australian agriculture: past, present and future. Journal of Applied Phycology. 2015 Oct;27(5):2007-15. http:// doi.org/10.1007/s10811-015-0574-9

22. Craigie JS. Seaweed extract stimuli in plant science and agriculture. Journal of applied phycology. 2011 Jun;23(3):371-93.

23. Ogwuike P, Rodenburg J, Diagne A, Agboh-Noameshie AR, Amovin-Assagba E. Weed management in upland rice in subSaharan Africa: impact on labor and crop productivity. Food Security. 2014 Jun;6(3):327-37. http://doi.org/10.1007/s12571-0140351-7

24. Chaturvedi I. Effect of nitrogen fertilizers on growth, yield and quality of hybrid rice (Oryza sativa). Journal of Central European Agriculture. 2005;6(4):611-8.

25. Kadidaa B, Sadimantara GR, Safuan LO. Genetic diversity of local upland rice (Oryza sativa L) genotypes based on agro- 
nomic traits and yield potential in marginal land of North Buton Indonesia. Asian Journal of Crop Science. 2017;9(4):109-17.

26. Khan AS, Muhammad I, Muhammad A. Estimation of genetic variability and correlation for grain yield components in rice (Oryza sativa L.). American-Eurasian Journal of Agricultural and Environmental Science. 2009;6(5):585-90.

27. Bhadru D, Reddy DL, Ramesha MS. Correlation and path coefficient analysis of yield and yield contributing traits in rice hybrids and their parental lines. Electronic Journal of Plant Breeding. 2011;2(1):112-6.

28. Bejo S, Zulkifli Z, Muharam F. Effect of nitrogen fertilizer to growth, biomass and grain yield of paddy. ISHS Acta Horticulturae. 2020. http://doi.org/10.17660/ActaHortic.2017.1152.22

29. Marhoon IA, Abbas MK. Effect of foliar application of seaweed extract and amino acids on some vegetative and anatomical characters of two sweet pepper (Capsicum Annuum L.) cultivars. International Journal of Research Studies in Agricultural Sciences. 2015;1(1):35-44.

30. Wang Y, Lu J, Ren T, Hussain S, Guo C, Wang S, Cong R, Li X. Effects of nitrogen and tiller type on grain yield and physiological responses in rice. AoB Plants. 2017 Mar 1;9(2). http://doi.org/ 10.1093/aobpla/plx012

31. Sunarpi H, Pebriani SA, Ambana Y, Putri FE, Nikmatullah A, Ghazali M, Kurnianingsih R, Prasedya ES. Effect of inorganic fertilizer and brown alga solid ectract on growth and yield of rice plants. InAIP Conference Proceedings 2019 Dec 23 (Vol. 2199, No. 1, p. 070006). AIP Publishing LLC. https://doi.org/ $10.1063 / 1.5141320$

32. Vijayanand N, Ramya S S and Rathinavel S. Potential of liquid extracts of Sargassum wightii on growth, biochemical and yield parameters of cluster bean plant. Asian Pacific J Reprod. 3(2): 2014. https://doi.org/10.1016/S2305-0500(14)60019-1

33. Rocha L, Temanel B, Desamiro N. Performance of upland rice at different fertilization practices. China. Journal of Food Processing and Technology. 2016.

34. Oo AN, Banterng P, Polthanee A, Trelo-Ges V. The effect of different fertilizers management strategies on growth and yield of upland black glutinous rice and soil property. Asian journal of plant sciences. 2010;9(7):414. http://doi.org/10.3923/ ajps.2010.414.422

35. Fayisa BA, Welbira GD. Influence of phosphorous and nitrogen fertilizer rate on grain yield of rice at Kamashi zone of Benshalgul Gumuz region, Ethiopia. Journal of World Economic Research. 2016;5(2):8-14. http://doi.org/10.11648/ j.jwer.20160502.11

36. Layek J, Das A, Idapuganti RG, Sarkar D, Ghosh A, Zodape ST, Lal R, Yadav GS, Panwar AS, Ngachan S, Meena RS. Seaweed extract as organic bio-stimulant improves productivity and quality of rice in eastern Himalayas. Journal of Applied Phycology. 2018 Feb;30(1):547-58. https://doi.org/10.1007/s10811-017-1225-0

37. Sharada P, Sujathamma P. Effect of organic and inorganic fertilizers on the quantitative and qualitative parameters of rice (Oriza sativa L.). Current Agriculture Research journal. 2018 Aug 1;6(2):166. https://doi.org/10.12944/CARJ.6.2.05

\section{Additional information}

Peer review information: Plant Science Today thanks Sectional Editor and the other anonymous reviewers for their contribution to the peer review of this work.

Reprints and permissions information is available at https://horizonepublishing. com/journals/index.php/PST/open_access_policy

Publisher's Note: Horizon e-Publishing Group remains neutral with regard to jurisdictional claims in published maps and institutional affiliations.

To cite this article: Sebastian HGG. Growth and yield performance of rice cultivars (Oryza sativa L.) under seaweed extract and inorganic fertilizer. Plant Science Today. 2021;8(4):933-940. https://doi.org/10.14719/pst.2021.8.4.1072

Plant Science Today, published by Horizon e-Publishing Group, is covered by Scopus, Web of Science, BIOSIS Previews, Clarivate Analytics, etc. See https://horizonepublishing.com/journals/index.php/PST/indexing_abstracting 